\title{
Immunohistochemical, Morphological and Ultrastructural Resemblance between Dendritic Cells and Folliculo-Stellate Cells in Normal Human and Rat Anterior Pituitaries
}

\author{
Wilfried Allaerts' ${ }^{1}$, Donna M. Fluitsma ${ }^{3}$, Elisabeth C. M. Hoefsmit ${ }^{3}$, Pieter H. M. Jeucken ${ }^{1}$, Hans Morreau ${ }^{2}$, Fred T. Bosman ${ }^{2}$, \\ and Hemmo A. Drexhage ${ }^{1}$ \\ 'Immunology Department and ${ }^{2}$ Pathology Department, Erasmus University Rotterdam, PO Box 1738, 3000 DR Rotterdam, \\ the Netherlands. \\ "Cell Biology and Immunology Department, Free University Amsterdam, Van der Boechorststraat 7, 1081 BT Amsterdam, \\ the Netherlands.
}

Key words: dendritic cells, folliculo-stellate cells, anterior pituitary, immunohistochemistry, immuno-electron microscopy.

\section{Abstract}

Immunolabeling of cryo-sections of human anterior pituitaries obtained at autopsy, and of cryo-sections of freshly prepared rat anterior pituitaries, with a panel of monoclonal antibodies against markers of the monocyte/dendritic cell/macrophage lineage, reveals in both species a characteristic pattern of immunopositive cells, among which many cells with dendritic phenotype are found. Cells characterized by marker expression of MHC-class II determinants and a dendritic morphology are present in both human and rat anterior pituitary. Markers characteristic of dendritic cells such as the L25 antigen and the OX62 antigen were present in anterior pituitaries from human and rat respectively. The population of MHC-class II expressing dendritic cells of the rat anterior pituitary is compared at the ultrastructural level with the folliculo-stellate cell population, which cell type has been previously characterized by its distinctive ultrastructure and immunopositivity for the $\mathbf{S 1 0 0}$ protein. Using immuno-electron microscopy of rat anterior pituitaries fixed with periodate-lysineparaformaldehyde, we were able to distinguish non-granulated cells expressing MHC-class II determinants, whereas no MHC-class II expression was found in the granulated endocrine cells. Using double immunolabeling of cryo-sections of these rat AP with $25 \mathrm{~nm}$ and $15 \mathrm{~nm}$ gold labels, we demonstrated an overlap between the populations of MHC-class II-expressing and S100 protein-expressing cells. Furthermore, MHC-class $\mathrm{II}$-expressing and S100-positive cells showed ultrastructural characteristics that have been previously ascribed to folliculo-stellate cells. At the light microscopical level in the rat AP, a proportion of 10 to $20 \%$ of the S100-positive cells was found immunopositive for the MHC-class II marker OX6. In the human AP, S100-positive folliculo-stellate cells and cells expressing the leukocyte common antigen CD45 were found to occupy predominantly different tissue compartments in the human anterior pituitary, namely the epithelial parenchyme cords and perivascular compartments respectively. A proportion of $\mathrm{CD}_{4} 5^{+}$cells was found in the parenchyme compartment and, vice versa, indicating an overlap of the tissue compartments in which both cell types occur. However, at the light microscopical level we could not find cells expressing both the $\$ 100$ and CD45 marker. The present finding of a proportion of $\$ 100$-positive pituitary cells with ultrastructural and immunohistochemical characteristics of both dendritic cells and folliculo-stellate cells, confirms the suggested heterogeneity of the latter cell group with respect to their ultrastructural phenotype and putative function. The possibility of a myeloid origin of part of the folliculo-stellate cell group in the AP, is discussed and might elucidate some of the discrepancies in the literature concerning the embryological origin of this cell group.

Dendritic cells (DC) with the exception of follicular dendritic cells $(1,2)$ are defined as a distinct class of cells that are believed to originate from the bone marrow (3). They are found in lymphoid as well as non-lymphoid organs and in peripheral blood and lymph $(4,5,6)$. DC have been isolated from many different organs and tissue compartments $(7,8)$, and were identified in vitro by their intrinsic functional properties $(7,9)$, particularly by their $\mathrm{T}$ lymphocyte stimulating properties in the so-called mixed leukocyte reaction (10). To the same class of DC belong the epidermal Langerhans cells (LC) (11) and DC in the liver (12), the gastrointestinal tract (13), the respiratory tract (14) and in various endocrine organs like the thyroid $(15)$ and pancreatic islets (16). The most prominent features of the group of DC are the dendritic morphology and pronounced MHC-class II expression (17). Their outstanding capacity of antigen presentation to lymphocytes makes them more potent accessory cells in the immune response than macrophages $(\mathrm{m} \theta \mathrm{s})(18)$.

The presence of myeloid cells in the normal anterior pituitary 
18 Dendritic and folliculo-stellate cells in anterior pituitary

(AP) has received only limited interest until now. However, a stellate-shaped, non-hormone secreting cell type has long been described as a normal constituent of the anterior pituitary (19), and because of its association with the AP follicular cavities, was called folliculo-stellate (FS) cell (20). These FS cells constitute a network throughout the AP, and are immunopositive for the S100 protein, which is thought to be a neuroectodermal marker $(21,22)$. Functionally, these FS cells were characterized by their ability to regulate pituitary hormone secretion in vitro $(23,24)$. The similarity between the network of S100 immunopositive FS cells and MHC-class II-expressing DC in the mouse and rat AP, was first described by our research group (25). In the present study, a detailed analysis of the immunophenotype and localization within the AP of cells of the monocyte/DC/m $\theta$ lineage and FS cells is elaborated, using immunohistochemistry of the AP of normal humans obtained at autopsy and normal rats, and using immuno-electron microscopy of the AP of normal Wistar rats. Moreover, using double immunolabeling techniques at the light optical (LO) and electron microscopical (EM) level, we investigated the possible overlap between DC and FS cells within the AP.

\section{Results}

\section{Pattern of $S 100$ immunostaining in human anterior pituitary $(A P)$}

Immunoperoxidase staining of paraffin sections of human AP with the (polyclonal) $\mathrm{S} 100$ antiserum reveals stellate-shaped positive cells scattered throughout the entire gland, corresponding to the description of $\mathrm{S} 100^{+} \mathrm{FS}$ cells in the rat $(22,21)$ and human AP (26) (Fig. 1A). S100 ${ }^{+}$cells were found in clusters or scattered among granulated endocrine cells, and the long slender cytoplasmic processes of these cells extending between granulated cells were also immunopositive (Fig. 1A). In paraffin sections the localization of $\mathrm{S}_{100^{+}}$cells within the AP was mainly restricted to the epithelial parenchyme cords (27), although a few $\mathrm{S} 100^{+}$ cells were found in the perivascular compartment close to capillary lumina. In cryo-sections of human AP immunostained with the $\mathrm{S} 100$ antiserum, a clustered distribution of $\mathrm{S} 100^{+}$cells was also found, but here immunoreactivity was predominantly localized in the cell nucleus and perinuclear cytoplasm, which is consistent with the diffusible nature of the $\mathrm{S} 100$ protein being a member of the $\mathrm{Ca}^{2+}$-binding protein family $(28,29)$. In the absence of formaldehyde-based fixatives, S100 immunoreactivity of cryosections showed in fact a diffuse, poorly circumscribed staining pattern, possibly due to leakage of the protein out of the cell. Cryo-sections of human AP therefore were not used in double immunolabeling procedures involving the labeling with the S100 antiserum.

In the two non-adult subjects (S92-243 and 236), the AP were entirely negative for the $\mathrm{S} 100$ protein, which may be related to the immaturity of the anterior pituitary. Interestingly, Coates \&
Doniach (30) described that S100 immunoreactivity was absent in anencephalic pituitaries.

\section{Pattern of immunostaining of myeloid cells in human anterior pituitary}

A survey of the immunostaining pattern in the human AP for a series of monocyte/DC/m $\theta$-specific markers is given in Table 1 . No correlation was found between the post-mortem interval and the intensity of staining with this panel of markers. Numerous stellate-shaped cells bearing MHC-class 11 determinants (OKIa) (Fig. 2A) were found in cryo-sections of all human AP examined, including the non-adult subjects (cfr. above). Also, cells immunopositive for the leucocyte common antigen or T200 antigen (LCA; CD45) (Fig. 1B) were found in all subjects but one, although in this specimen $\mathrm{CD} 45^{+}$cells were indeed found in the paraffinembedded material (Table 1). Morphologically, the $\mathrm{CD} 45^{+}$cells were characterized as either of lymphocyte phenotype or of dendritic phenotype, with numerous fine cytoplasmic processes (Fig. 2B). In paraffin sections the $\mathrm{CD}_{4} 5^{+}$cells appeared within the lumina of blood vessels, the perivascular compartment and the larger connective spaces (Fig. 1B), but very few $\mathrm{CD} 45^{+}$cells were found in the epithelial parenchyme compartment. The expression of the Langerhans cell marker CDla and the monocyte marker CDI4 was variable in the human APs examined, varying from no or only moderate expression for the CD1a antigen and none or abundant expression for the CDI4 antigen. However, a proportion of the $\mathrm{CD} 14^{+}$cells in some heavily stained AP were localized around follicle-like structures (Fig. 2D). Also, dendriticlike cells expressing the L25 antigen (31) were found in high density in some pituitaries (Fig. 2C).

Using a double immunolabeling procedure with a peroxidase staining followed by an APAAP staining method, we found partially overlapping cell populations immunopositive for CD14 and CD45 that also partially expressed the MHC-class II determinant OKIa (Fig. 1D). Moreover, a proportion of the population of $\mathrm{CD}_{4} 5^{+}$cells was positive for the CDla marker (Fig. 1E). However, double immunolabeling of paraffin sections with the S100 and CD45 antibodies revealed that most of the CD45 ${ }^{+}$cell population was distinct from the $\mathrm{S} 100^{+}$cell population (Fig. 1C). At the light optical level, no clear indication was found of cells expressing both the S100 protein and CD45 marker.

\section{Pattern of S100, macrophage marker and MHC-çlass II expression in rat anterior pituitary}

In cryo-sections of rat AP post-fixed with Zamboni fluid and immunolabeled with the S100 antiserum, a distribution of positive cells was found reminiscent of the $\mathrm{S} 00^{+}$cells in human AP. $\mathrm{S} 100^{+}$cells showed a clustered distribution and were frequently found in association with follicle-like structures. In cryo-sections,

\footnotetext{
FIG. 1. A, B, C. Paraffin sections of human anterior pituitary immunostained with the polyclonal anti-S100 serum $(1 \mathrm{~A})(\times 340)$, with a mAb against the CD45 marker (1B) $(\times 544)$, and double-immunolabeled with the anti-S100 (red) and anti-CD45 sera (blue) (1C) $(\times 544)$. S100 ${ }^{+}$cells are mainly localized within the epithelial parenchyme cords, whereas $\mathrm{CD}^{+} 5^{+}$cells are predominantly found in the perivascular and connective spaces.

D, E. Cryo-sections of human anterior pituitary double-labeled with mAbs directed against the CD45 marker (blue) and MHC-class II determinants (red) (1D), and against the CD45 marker (red) and the CDla marker (blue) (1E) $(\times 857)$. Note the double immunolabeled cell (arrow) in 1E beside the cells immunolabeled with either the CD45 or CDla marker (separate red and blue stains). All sections shown are from adult human pituitaries obtained at autopsy. PV: perivascular compartment; EP: epithelial parenchyme compartment (Bars $=20 \mu \mathrm{m}$ ).
} 

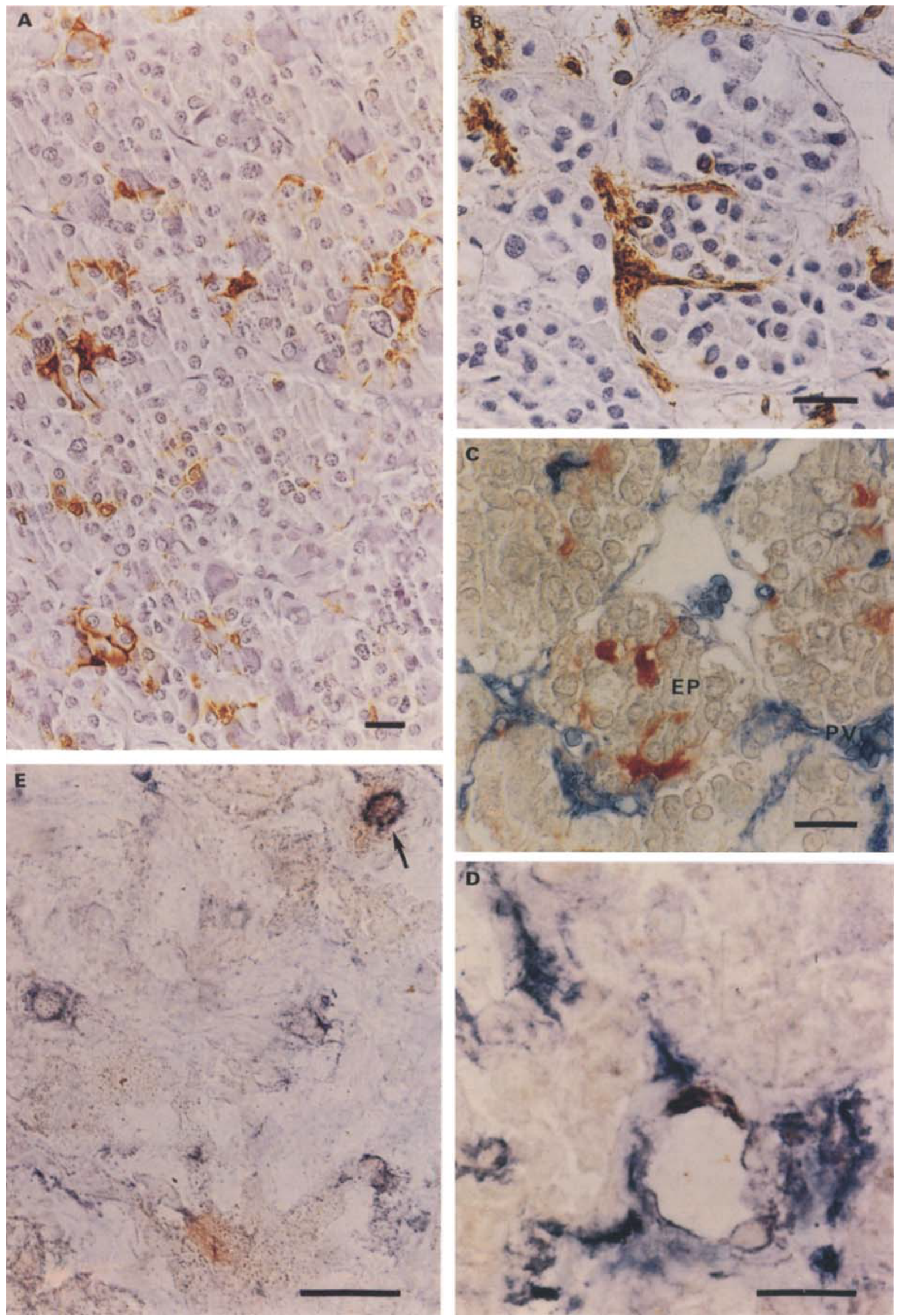

C 1996 Blackwell Science Ltd, Journal of Neuroendocrinology, 8, 17-29 
TABle 1. Immunostaining Pattern of Human AP with Monocyte/m $\theta /$ DC-Specific Markers and Anti-S100 Serum

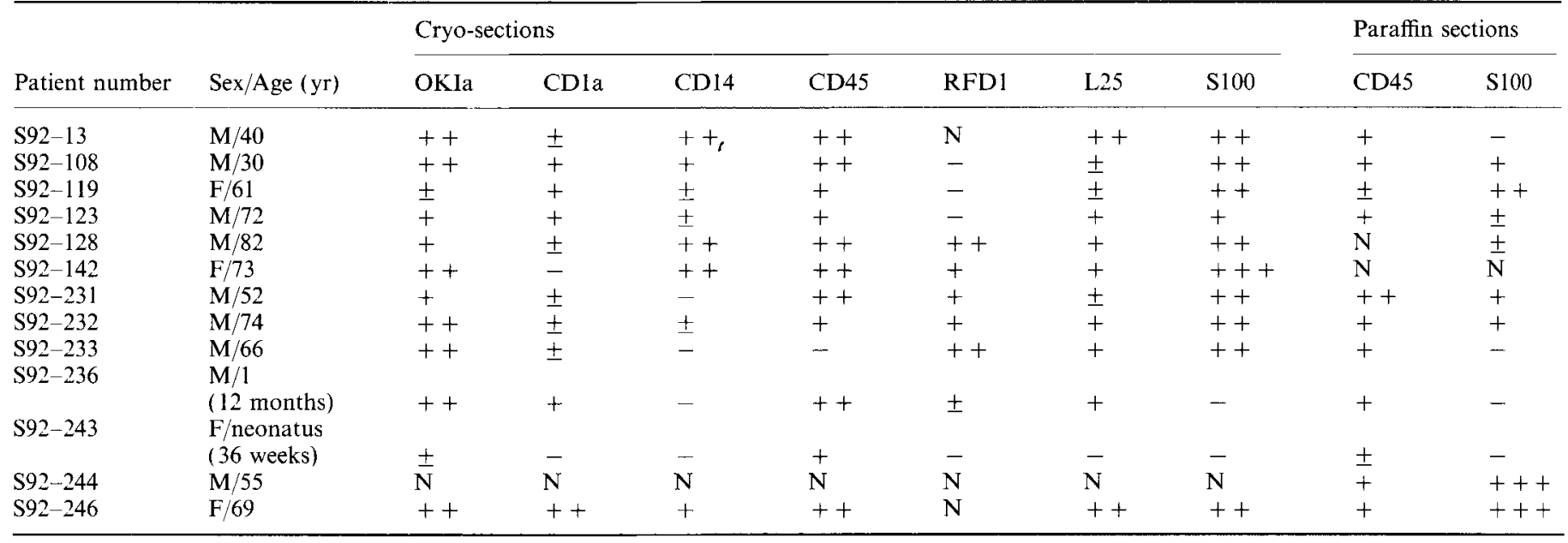

+++ abundant and clear positive staining; ++ numerous cells with distinct positive staining; + few cells with distinct positive staining; \pm weak reactivity; - no reactivity; N not determined.
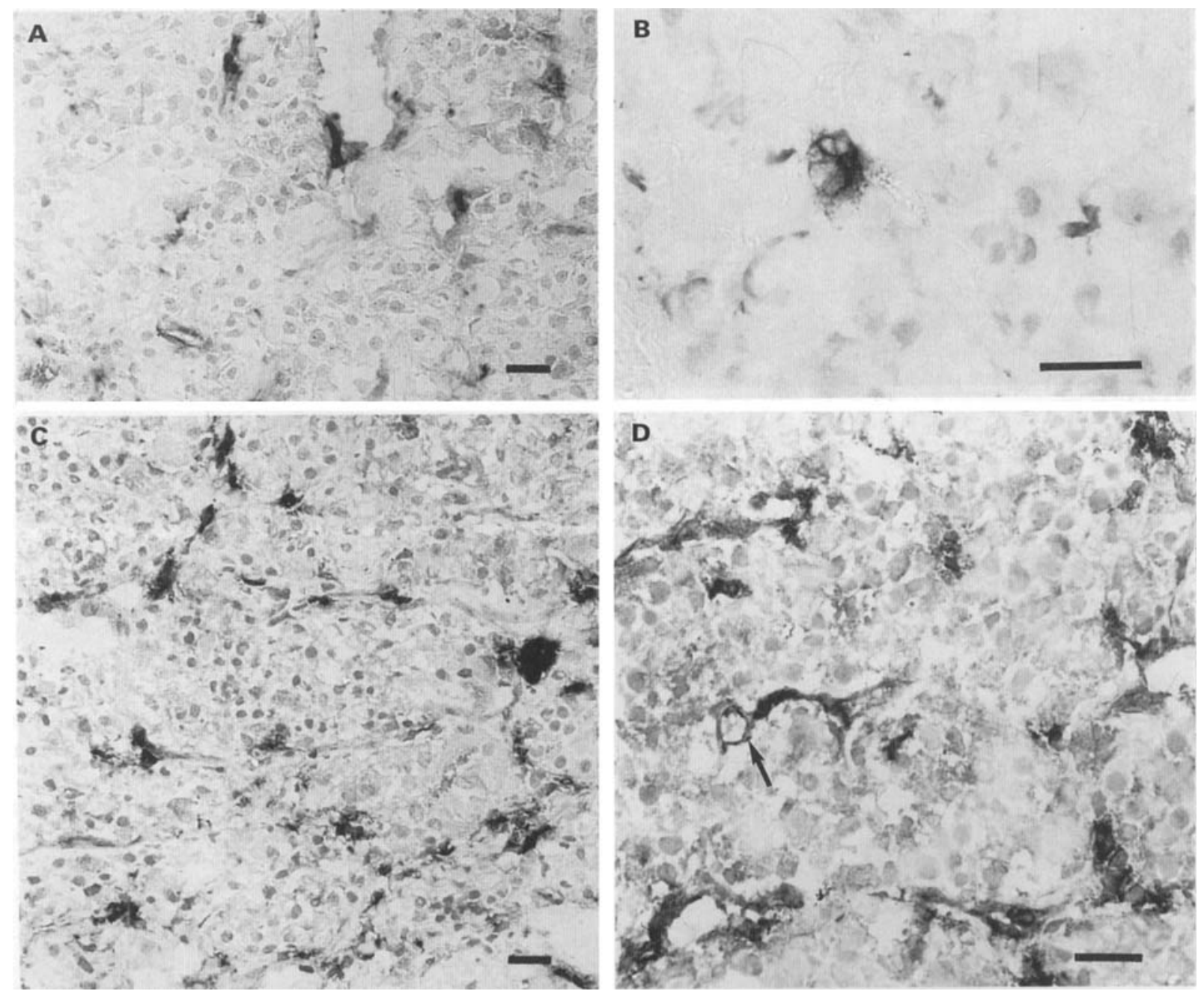

FIG. 2. Cryo-sections of human anterior pituitary immunostained with mAbs directed against MHC-class II determinants $(\mathrm{OKIa})(2 \mathrm{~A})(\times 272)$, against the CD45 marker (HLe-1) (2B) ( $\times$ o85), the L25 antigen (TB1-4D5) (2C) $(\times 272)$ and the CD14 marker (Leu-M3) (2D) ( $\times 435)$. Human pituitaries were obtained at autopsy from adult subjects. Note the $\mathrm{CD}_{4} 5^{+}$cell with dendritic-like phenotype in $2 \mathrm{~B}$, and the CD14 ${ }^{+}$cells localized around a folliclelike structure (arrow) in 2D (Bars $=20 \mu \mathrm{m})$. 
staining was mainly localized in the cell nucleus of these $\mathrm{S} 100^{+}$ cells, although a few cytoplasmic processes could be identified.

Immunolabeling of adjacent sections of this rat AP with the MHC-class II marker (OX6) revealed less numerous positive cells (Table 2), but with a similar distribution as the $S 100^{+}$cells. The ratio of the $\mathrm{OX}^{+}$cell number to the $\mathrm{S} 100^{+}$cell number in these adult female rats was about $30 \%$ (Table 2 ). At the light optic level the OX6 mAb stained the cytoplasm, including some (mostly short) processes. Some of the MHC-class II-expressing cells were found adjacent to follicle-like structures (not shown in figure). The recently described DC marker OX62 (33) was sparsely present in the rat $\mathrm{AP}$ (Fig. $3 \mathrm{~A})$. With regard to the $\mathrm{m} \theta$-markers $\mathrm{ED} 1,2,3,7,8,9(34,35)$ in normal Wistar AP, only very few immunopositive cells were found. Small numbers of cells weakly positive for the ED1, ED2 (Fig. 3B) and ED7 markers were found, but immunoreactivity with the ED3, ED8 and ED9 markers was absent. A quantitative comparison of the densities of $\mathrm{MHC}$-class II positive, $\mathrm{S} 100^{+}, \mathrm{OX}_{62}{ }^{+}$, and $\mathrm{ED}^{+}$and $\mathrm{ED}^{+}$ cells is given in Table 2 . Using a double immunolabeling of cryosections of rat AP after PLP fixation, according to the fixation procedure used for immuno-electron microscopy (see below), we found a clear overlap between the populations of $\mathrm{S}_{100}{ }^{+}$and $\mathrm{OX}^{+}$cells (Fig. 4). About 10 to $20 \%$ of the S100 ${ }^{+}$cells were also immunopositive for the OX6 marker. A number of $\mathrm{OX}^{+}$ cells was not immunopositive for the $\mathrm{S} 100$ marker. A similar pattern of overlap was seen between the populations of $\mathrm{S}_{100^{+}}$ and $\mathrm{OX} 62^{+}$cells (data not shown in Fig.).

Ultrastructure of S100 positive and MHC-class II positive cells in rat anterior pituitary

Ultrathin HM20 sections of rat AP gave excellent topography and morphology of the preselected areas. Immunogold labeling

TABLE 2. Relative Densities of Immunopositive Cell or Nucleus Profiles in Cryo-Sections of Rat Anterior Pituitary*.

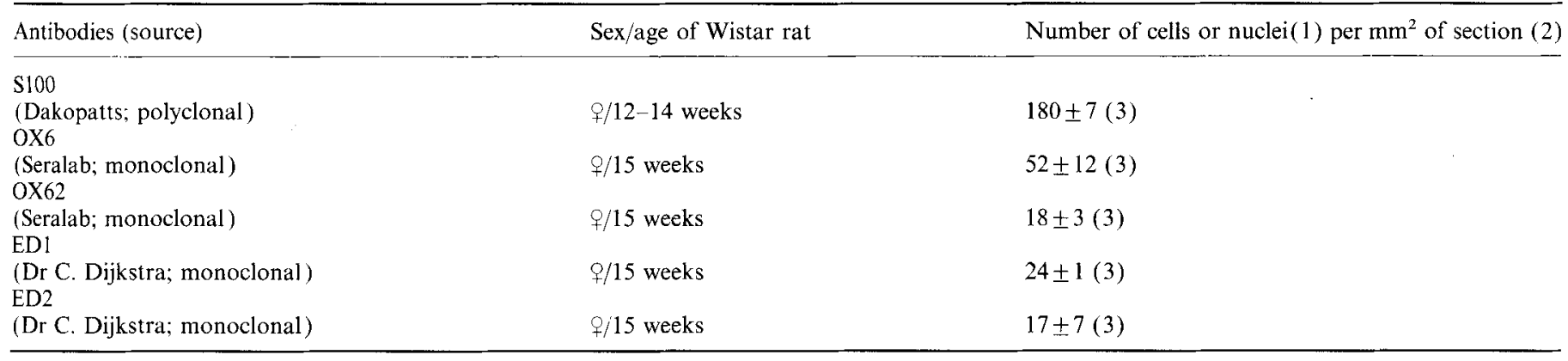

* Cryo-sections are post-fixed with Zamboni-fixative (S100 antibody) or acetone (other antibodies) as described in the Materials and methods section. ${ }^{1}$ In the S100 immunostained cryo-sections cell nuclei were counted, because of the marked labeling of these nuclei. In the cryo-sections labeled with monoclonal antibodies, the numbers of immunopositive cells represent the numerical areal densities of whole cell profiles (32).

${ }^{2}$ Mean \pm SEM ( $\mathrm{n}=$ number of pituitaries).
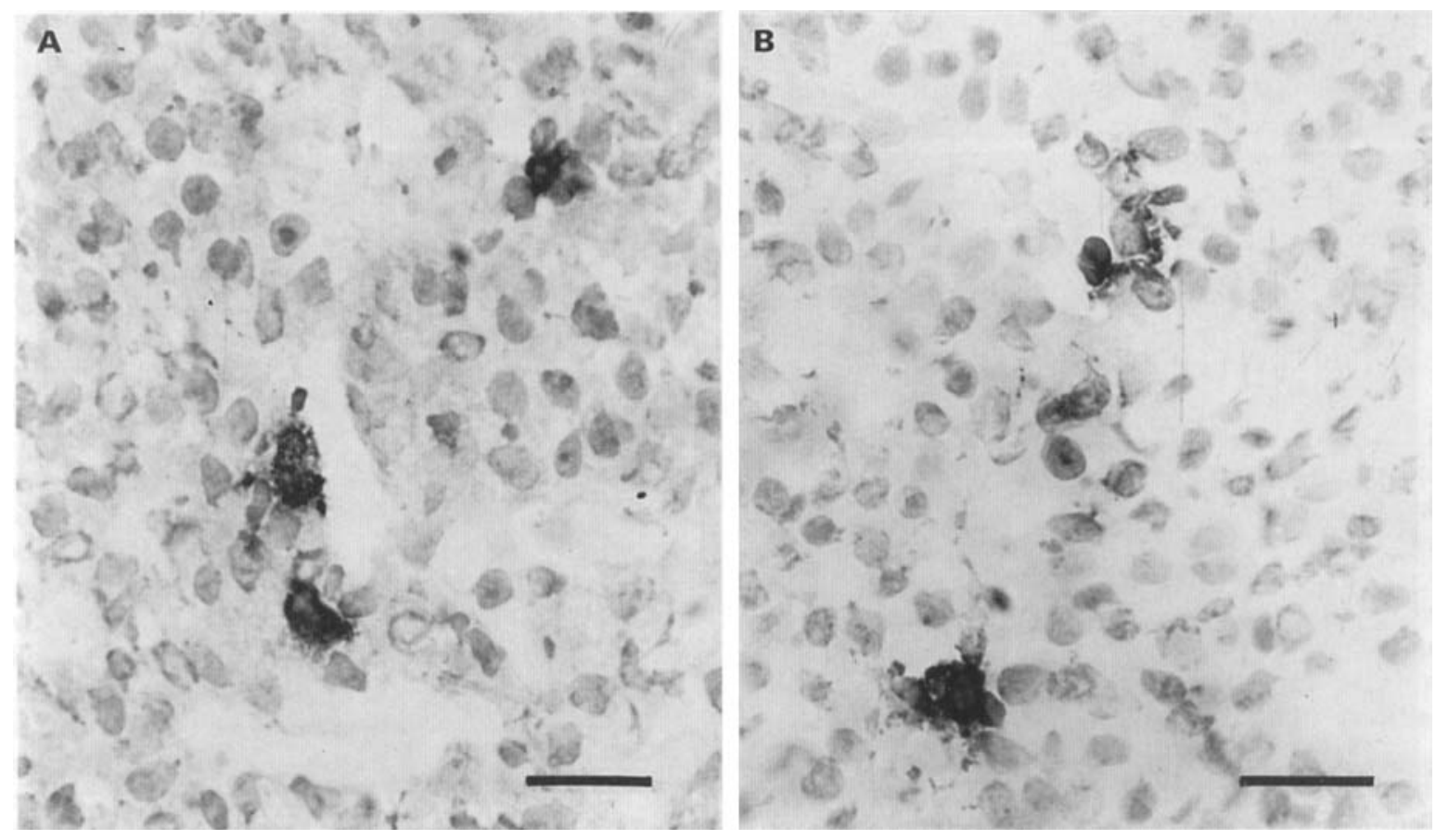

Fig. 3. Cryo-sections of rat anterior pituitary immunostained with the OX62 mAb $(3 \mathrm{~A})(\times 672)$ and the ED2 marker $(3 \mathrm{~B})(\times 672)(\mathrm{Bars}=20 \mu \mathrm{m})$. 
Dendritic and folliculo-stellate cells in anterior pituitary
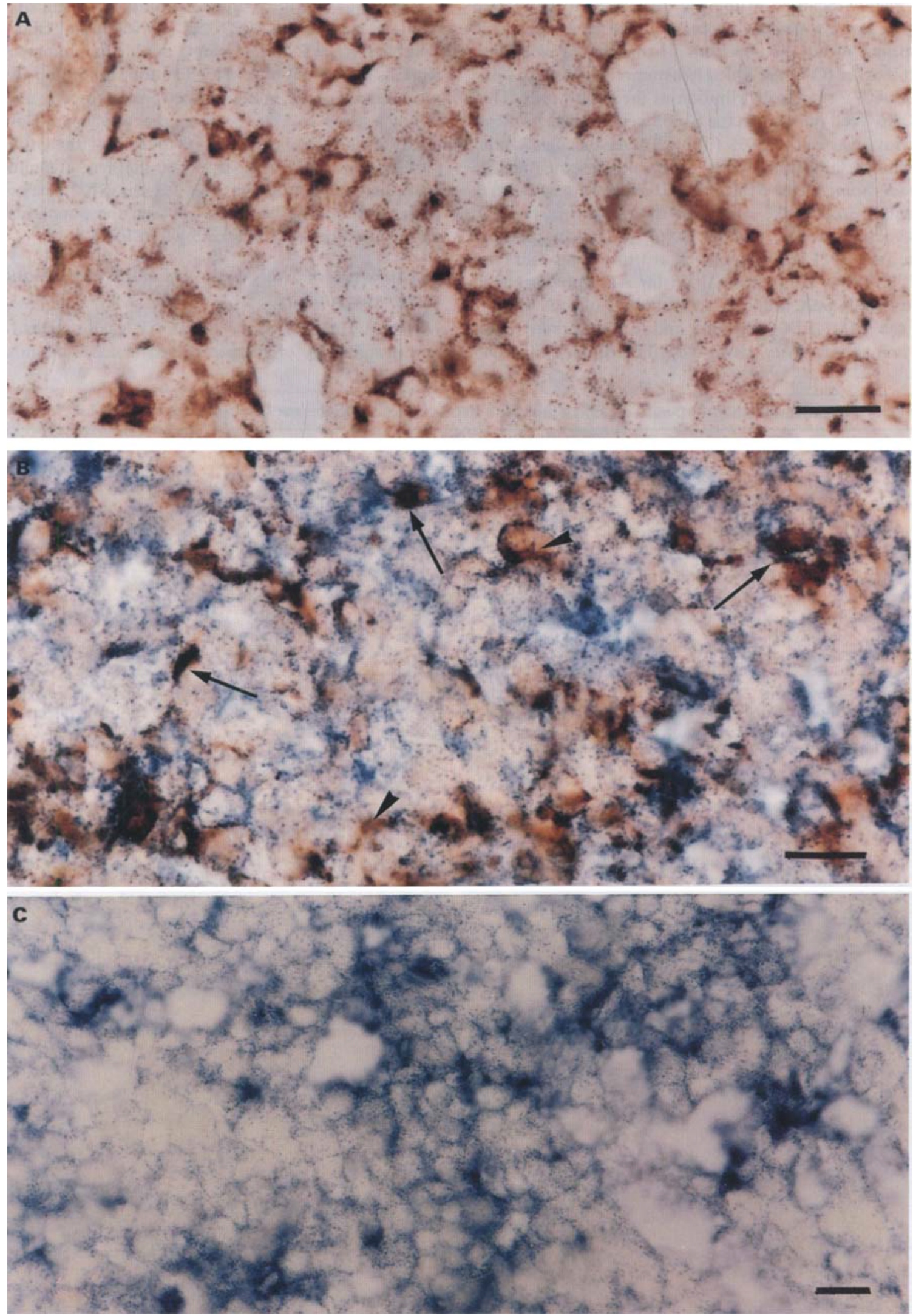

FIG. 4. Cryo-sections of PLP-fixed rat anterior pituitary immunolabeled with the anti-S100 serum (4A) $(\times 672)$, double-immunolabeled with the antiS100 serum (red) and OX6 mAb (blue) (4B) $(\times 672)$, and immunolabeled with the OX6 mAb $(4 \mathrm{C})(\times 426)$. Note the double-immunopositive cells (arrows) and some cells only labeled with the anti-S100 serum (arrowheads) in 4B. Also, cells only labeled with the OX6 mAb are clearly distinguished (blue stain) in $4 \mathrm{~B}$. (Bars $=20 \mu \mathrm{m})$.

(C) 1996 Blackwell Science Ltd, Journal of Neuroendocrinology, 8, 17-29 


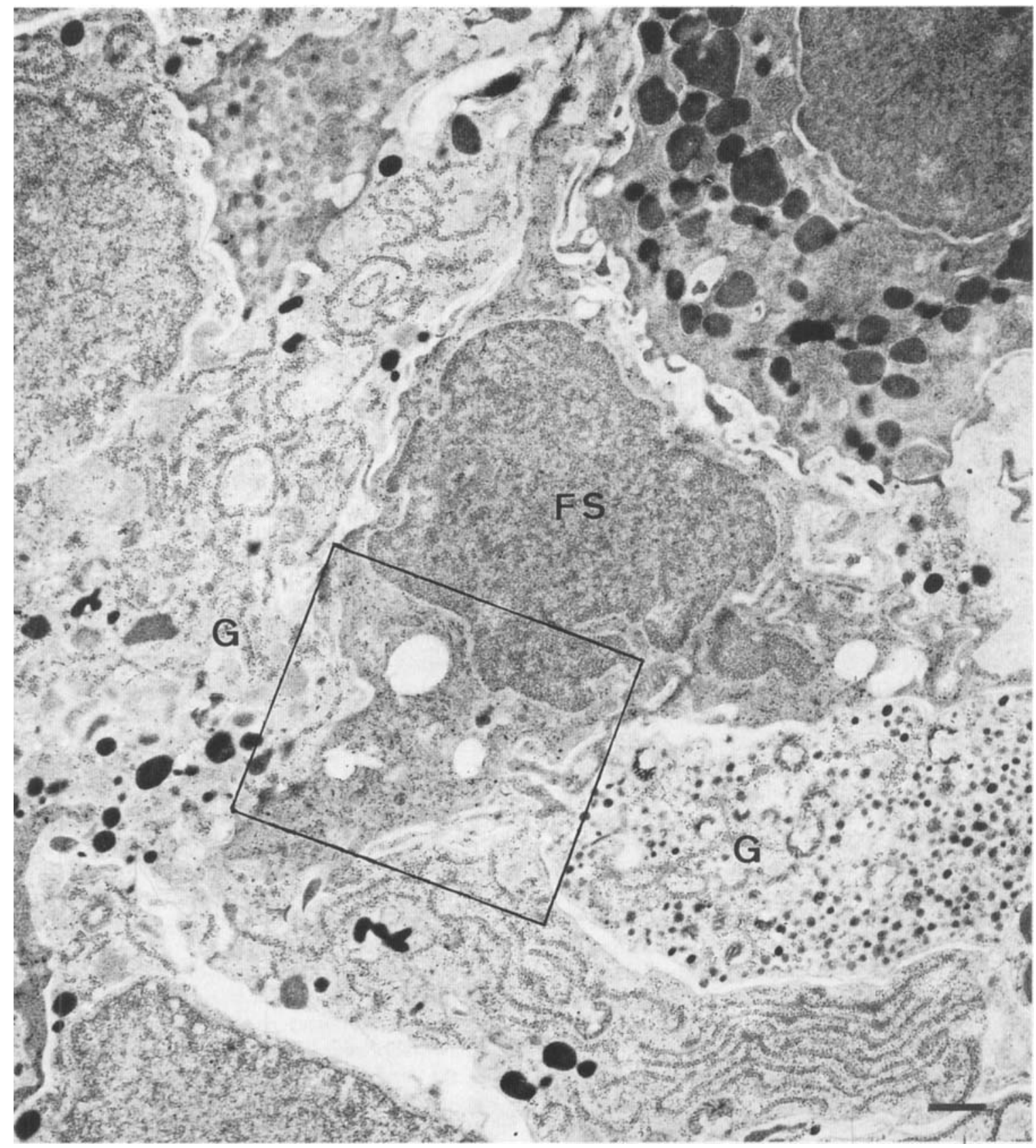

FIG. 5. Ultrathin Lowicryl HM20 section of rat AP giving an overview of a FS cell (FS) surrounded by granulated endocrine cells (G) ( $\times 16120$; bar $=0.5 \mu \mathrm{m}$ ). A high power magnification of the frame is shown in Fig. 6 .

with the polyclonal S100 antiserum of HM20 sections (Fig. 5 and 6 ) revealed cells reminiscent of the folliculo-stellate (FS) cell type as described by Vila-Porcile (20).

Immunogold labeling with the MHC-class II specific mAb OX6 of the HM20 sections, showed fewer labeled cells corresponding with the light-optical staining pattern of $\mathrm{S} 100^{+}$and $\mathrm{OX}^{+}$cells (Table 2). Using a double immunogold-labeling procedure with gold particles of $15 \mathrm{~nm}$ and $25 \mathrm{~nm}$ diameter respectively, we were able to identify FS cells bearing both the S100 protein and OX6 antigen markers (Fig. 5-6). Ulirathin cryosections on the other hand, did not so well preserve the topography of preselected areas, but immunolabeling was more sensitive for both the $\$ 100$ and the OX6 markers in the cryo-sections than in the HM20 sections (see also ref. 74). Background labeling was absent, for granule-bearing endocrine cells were not labeled with the gold particles.

$\mathrm{S} 100^{+}$cells with stellate, elongated or triangular shape on section were found surrounded by a number of granule-bearing endocrine cells ( Fig. 5), indicating a predominantly parenchymal localization. Gold particles labeling the S100 protein were found both in the cell nucleus and cytoplasm (Fig. 6).

Gold particles labeling the OX6 antigen were frequently found associated with the cell membrane, but were also found within intracellular vesicles (36) (Fig. 6). Ultrastructurally, the $\$ 100$ 
24 Dendritic and folliculo-stellate cells in anterior pituitary

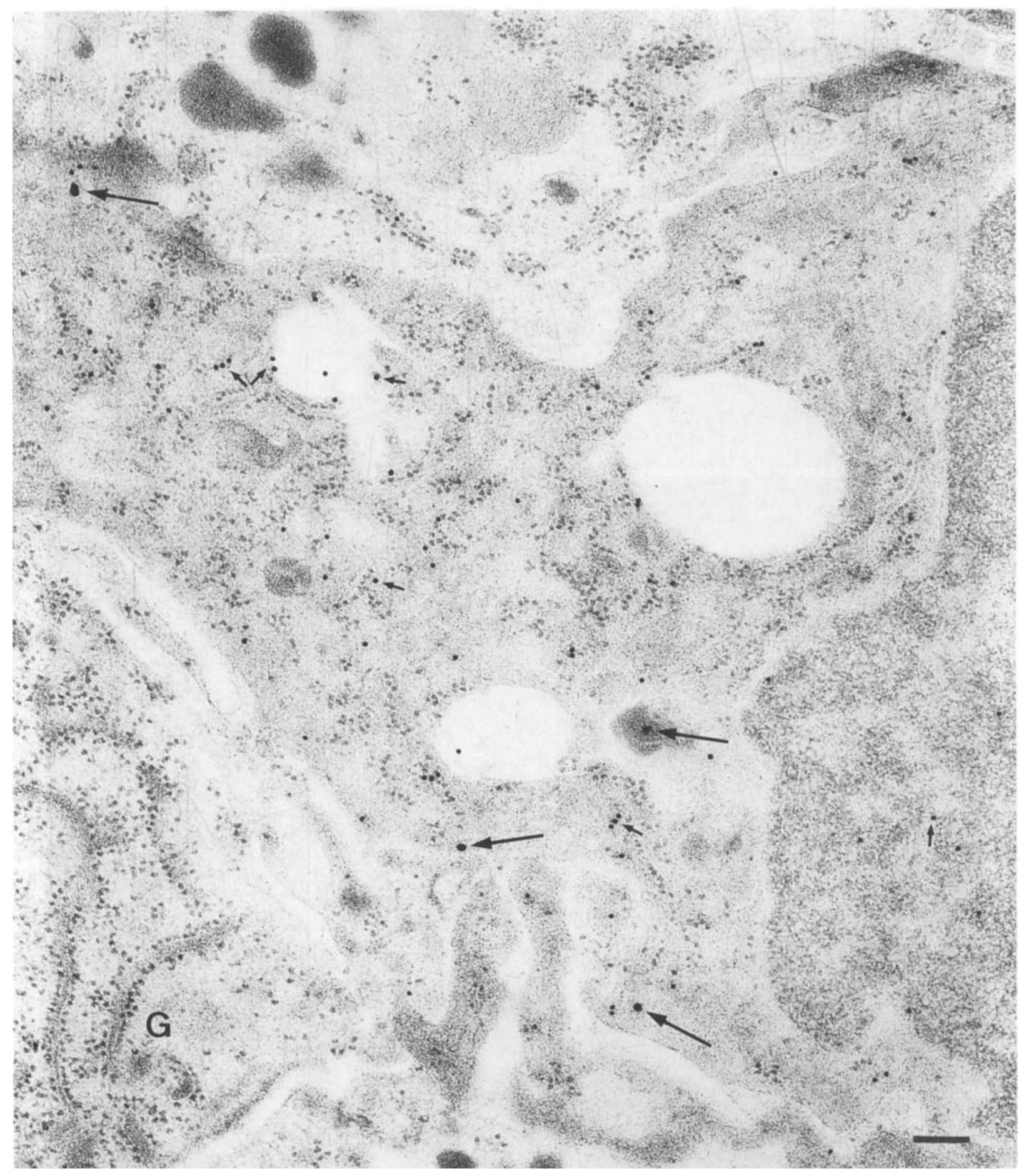

FIG. 6. Ultrathin Lowicryl HM20 section of rat AP showing a detail of Fig. 5: a FS cell is shown at high magnification, labeled for S100 protein ( $15 \mathrm{~nm}$ gold label; shorter arrows) and for MHC-class II determinants ( $25 \mathrm{~nm}$ gold label; longer arrows) $(\times 40660$; bar $=0.2 \mu \mathrm{m})$. No gold label is found within the granulated endocrine cell $(\mathrm{G})$.

positive and OX6 positive and double-positive cells, displayed characteristics ascribed to both 'classical' FS cells and 'classical' DC, such as a more or less indented nucleus, microvillous projections, many large intracellular vesicles (including lipid droplets and phagolysosomes), elongated or vermiform mitochondria (20) and centrioles. We recently described in more detail several of these ultrastructural characteristics in double immunolabeled $\left(\mathrm{S} 100^{+} \mathrm{OX}^{+}\right)$cells in ultrathin cryo-sections of the rat AP (74). Birbeck granulae were not found in the AP cells labeled with either the S100 or OX6 markers. Clusters of FS cells surrounding a follicle, wherein microvillous protrusions are found, were also immunopositive for the $\mathrm{S} 100$ and OX6 markers. The 
ultrastructural characteristics, immunopositivity for S100 and the topographical localization (24), indicate that this cell type corresponds to the classical FS cells, as described by Vila-Porcile (20).

\section{Discussion}

In the present paper the distribution of cells labeled with markers of myeloid cells is described in the AP of human and rat. These data corroborate our previous observations of dendritic-like cells in the rat and mouse pituitary (25). We discuss here how these cells are related to the earlier described FS cells in the AP of various mammals including man $(20,26,37,38)$, because DC and FS cells are very similar at the ultrastructural level. FS cells were described as non-hormone secreting cells with a stellate morphology in the AP $(20,26,37,38)$, that are also immunopositive for the $\mathrm{S} 100$ protein which was believed to be a neuroectodermal marker $(21,22)$. A number of immunohistochemical studies revealed that the $\mathrm{S} 100$ protein is also expressed in the skin Langerhans cell (LC) (39), in the interdigitating reticulum cell of the lymph node (40) and in dendritic cells at various locations (41). The importance of these data, together with the present description of dendritic cells in the AP, is highlighted in the following paragraphs. In our group $(15,16,42)$ DC are defined as MHC-class II strongly positive cells with dendritic morphology and a limited acid phosphatase activity localized in a juxtanuclear spot $(42,43)$. Further criteria are a reniform or indented nucleus, and the reactivity to various monoclonal antibodies like in the human RFD1 (44) and the L25 antigen (31) (Fig. 2C and Table 1), and in the rat, the OX62 antigen (33) (Fig. $3 \mathrm{~A}$ ).

The ultrastructural characteristics of most of the MHC-class II-expressing cells in our study are similar to those of DC described in other lymphoid tissues (5). Birbeck granulae (45) the hallmark of LC however, were not found in the pituitary. Part of these MHC-class II positive cells, coincided with the earlier described FS cells (20). We recently described typical vermiform mitochöndria, lipid droplets, phagolysosomes and centrioles in the FS-cell like $\mathrm{OX} 6^{+}$cells (74), which characteristics in the AP are classically ascribed to FS cells (20). According to Steinman \& Cohn (7) some of these characteristics may also be found in DC (lipid droplets, microvilli, and centrioles), whereas phagolysosomes have been characterized in DC in situ (42). The FS-cell-like cells showed a weak staining with the OX6 antibody, but were frequently labeled with the S100 antibody. FS cell heterogeneity has been described at the light optical (46) and ultrastructural level (47). It is possible that this heterogeneity is reflected in the variable expression of the MHC-class II determinants.

At the light optical level, in cryo-sections of PLP-fixed rat AP, a proportion of about $10-20 \%$ of the $\mathrm{S} 100^{+}$FS cells was found immunopositive for the MHC-class II-marker OX6 (Fig. 4). This double immunolabeled cell population probably corresponds at the EM level with the double immunolabeled cells ( $\mathrm{S} 100^{+} \mathrm{OX}^{+}$) found in the endocrine parenchyme compartment (Figs. 5 and 6). Comparison of the relative cell numbers found when applying single or double immunolabeling procedures, was suggestive for a relative decrease of $\mathrm{S} 100$ antigenicity in the double immunolabeling procedure. This decrease of $\mathbf{S 1 0 0}$ antigenicity of cryo-sections in the double immunolabeling procedure was seen as a slight reduction of the number of immunopositive cells. This finding is in agreement with the diffusable nature of the S100 protein as observed in cryo-sections of human and rat AP.

Recently, we observed (48) that FS cells and MHC-class II-expressing cells co-localize in the low density fractions of a BSA-sedimentation gradient. Since the numbers of S100 positive cells exceed the numbers of MHC-class II-expressing cells, both in situ and in low density BSA-gradient fractions (48) and since the two cell types are ultrastructurally very similar and labeled for both OX6 and S100 (Fig. 4, 6; ref. 74), we conclude that a distinct overlap (about $10-20 \%$ ) exists between the populations of pituitary FS cells and DC, or, in other words, a subpopulation of the FS cells corresponds with DC.

It was shown that also in the posterior lobe of the human pituitary, pituicytes were found that are immunopositive for MHC class II determinants and/or some macrophage markers (49). However, despite the overlap found between the populations of FS cells and DC in the rat AP, we were not able to demonstrate an overlap between $\mathrm{S} 100^{+}$cells and $\mathrm{CD} 45^{+}$cells in the human AP. CD45 is a marker of the myeloid origin of leukocytes, known as the T200 antigen (50). Using paraffin immunohistochemistry at the LO level, we demonstrated that $\mathrm{S} 100^{+}$cells and $\mathrm{CD} 45^{+}$ cells do not match with respect to the compartments in which they are localized, being the parenchymal cords or the perivascular connective tissue spaces, respectively (Fig. $1 \mathrm{~A}-\mathrm{C}$ ). However, a small number of $\mathrm{CD} 45^{+}$cells was also found in the parenchyme compartment. No co-localization was found within the same cell of both the S100 protein and the CD45 marker, which, however, may also be due to the limited resolution of the LO parafin immunohistochemistry. This confirms a previous observation of Vila-Porcile (27), with regard to a 'cellule d'aspect myoïde' or a presumptive myoid cell $(27$, p. 104) found in the perivascular compartment, but also in the parenchyme compartment. It should be noted that this cell type was described as a distinct cell type, that differed from the FS cells by a number of ultrastructural characteristics, like the relatively dense and indented nucleus and the short and bulbous cytoplasmic protrusions. However, the same so-called 'myoïd' cell also differed from the macrophage cell type described by the same author in the rat $\mathrm{AP}(27, \mathrm{p} .106)$. With regard to the mø's of the AP, Vila-Porcile (27) stated that these cells were always found in the proximity of the blood vessels. Moreover we found small numbers of cells with the macrophage phenotype immunopositive for the ED1, ED2 and ED7 markers in the rat $\mathrm{AP}(34,35)$. This indicates that beside the DC population also a $\mathrm{m} \theta$ population resides in the rat AP.

Our finding of an $\mathrm{S} 100^{+}$and $\mathrm{OX}^{+}$subpopulation of FS cells resembling $\mathrm{DC}$ in the rat $\mathrm{AP}$, and the absence of an overlap between the populations of $\mathrm{S} 100^{+}$and $\mathrm{CD} 45^{+}$cells in the human AP, raises some doubt with respect to the embryological origin of the FS cells as reported in the literature. First, the coincidence of S100 and OX6 markers within one cell type suggests that the population of FS cells of the AP might be heterogeneous, as was also described by others $(46,47,51)$. Since the $S 100$ protein is also expressed in bone-marrow derived DC, the neuroectoderm, as suggested by Cocchia \& Miani (21) and Nakajima et al. (22), or the oral ectoderm, as suggested by Gon (52) and Tachibana \& Yamashima (51), are probably not the only possible embryological sources of $\mathrm{S} 100^{+}$cells with dendritic phenotype within the AP. The possibility of a myeloid origin of part of the $\$ 100$ expressing FS cell population in the AP, remains to be elucidated.

With regard to the presence of $m \theta$ markers in the rat $\mathrm{AP}$, we 
have shown that the numbers of $m \theta s$ found were below the numbers of MHC-class II-expressing cells and far below the numbers of $\mathrm{S} 100^{+}$cells (Table 2). Since the markers ED1 and ED7 were reported to partly coincide between $\mathrm{m} \theta \mathrm{s}$ and $\mathrm{DC}(35)$, and since mouse $\mathrm{DC}$ are negative for the $\mathrm{m} \theta$ marker $\mathrm{F} 4 / 80$ present in the mouse $\mathrm{AP}(53,54,55)$, we may conclude that the population of pituitary $m \theta$ s may partly coincide with the DC-like cell population, but only to a very limited extent with the FS cell population. Further research will also be needed to explore the functional relationships between MHC-class II expressing DC and $\mathrm{S} 100^{+} \mathrm{FS}$ cells of the AP, by studying the functional behavior of subpopulations of these cells in culture.

It is well established that FS cells have an endocrine regulatory function, as was inferred from their ability to regulate pituitary hormone secretion in vitro (29). Moreover, recent evidence

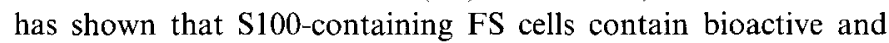
immunoreactive interleukin- 6 and are the likely producers of interleukin-6 in the AP (56). On the other hand, the immune regulatory function of $\mathrm{DC}$ is indicated by their capacity of antigen presentation to $\mathrm{T}$-lymphocytes (10) and pituitary derived $\mathrm{DC}$ are capable of stimulating $\mathrm{T}$ cell proliferation in an allogeneic mixed leukocyte reaction assay (74 and unpublished observations). A possible myeloid origin of FSC-DC in the AP also has clinical relevance. Of 13 human pituitaries studied, the absence of $\$ 100$ expression was revealed in two paediatric cases, one of which had retarded brain development. It is tempting to speculate that the absence of S100 expression in the AP and the absence of certain markers of the DC lineage in the AP, are caused either by a common disturbance or by immaturity. Moreover, the present observation of DC within the AP further confirms the presence of $\mathrm{DC}$ in endocrine organs under non-pathological conditions $(15,16,57)$.

\section{Materials and methods}

\section{Human pituitary tissue}

Human pituitaries were obtained at autopsy from 11 adult subjects ( 8 male and 3 female), 1 female neonatus of 36 weeks old (pathology ref. S92-243) and 1 male child of 1 year old (pathology ref. S92-236). All subjects died from non-endocrine causes, such as coronary insufficiency or cancer. The post-mortem interval was between 6 and $24 \mathrm{~h}$. The age range of the adult subjects was between 30 and 82 years. One of the nonadult cases was diagnosed as a Potter syndrome with lung hypoplasia and renal agenesis ( $\$ 92-243$ ). The other one was suffering from microcephalic development with almost absent pituitary (S92-236).

Human pituitary tissues were divided into 2 parts: 1 part was embedded in Tissue-Tek (Miles Inc., Elkhart, IL, USA) and stored at $-80^{\circ} \mathrm{C}$; cryosections of 4 to $6 \mu \mathrm{m}$ were cut. A second part was fixed in $10 \%$ neutral buffered formalin and embedded in paraffin; sections of $5 \mu \mathrm{m}$ were cut.

\section{Rat pituitary tissue}

Adult male and female Wistar rats (3 months old) were prepared for cryo-immunohistochemistry as described previously (25). Male and female rats of 3 weeks up to 3 months of age were studied in parallel in a quantitative light microscopical study of DC development (data presented elsewhere). Pituitaries were embedded in Tissue-Tek and stored at $-80^{\circ} \mathrm{C}$. In addition, 6 adult female rat pituitaries were prepared for immunoelectron microscopy. Pituitary tissue was fixed with periodate-lysineparaformaldehyde (PLP) fixative on ice $\left(4^{\circ} \mathrm{C}\right)$ immediately after dissection according to McLean \& Nakane (58).

\section{Paraffin immunohistochemistry}

Primary antisera used on formalin fixed and paraffin embedded pituitary tissue were the polyclonal rabbit anti-bovine $\mathrm{S} 100$ protein (Dakopatts,
Glostrup, Denmark) (diluted 1:1200) and the monoclonal mouse-antihuman leukocyte common antigen (LCA) (CD45; Dakopatts) (diluted $1: 12.5)$. The paraffin sections were deparaffinized with absolute ethanol. Endogenous peroxidase activity was blocked by incubation with $3 \%$ methanol in distilled water for $25 \mathrm{~min}$, whereafter the sections were shortly rinsed with tap water. Single immunostaining procedures were performed according to the ABC-method (59) with 3,3'-diamino-benzidine (DAB) (Fluka, Buchs, Switzerland) as staining reagent. The secondary antiserum used was biotinylated goat-anti-mouse and rabbit immunoglobulin ( $\mathrm{Ig}$ ) serum (Dakopatts). Following the incubations with primary and secondary antisera, the sections were incubated with biotinylated peroxidase (biotine-HRP) together with streptavidin (both from Dakopatt's). Dilutions of antisera and washes between successive incubation steps were performed with $0.05 \mathrm{M}$ phosphate buffered saline (PBS, pH 7.4-7.6) with 0.05\% Tween-20 (Merck, Darmstadt, Germany).

Double immunostaining procedures consisted of a first staining sequence according to the ABC-method with a biotinylated secondary antibody (Multilink, Biogenex, San Ramon, CA, USA), streptavidin labeled alkaline phosphatase (Biogenex) and fast blue (Serva, Heidelberg, Germany) as staining reagent, and a second staining sequence according to the peroxidase-anti-peroxidase (PAP) method (60) with 3-amino-9ethylcarbazole (AEC) (Sigma, St. Louis, MO, USA) as staining reagent. To avoid interference between the two staining sequences, the sections were incubated for $10 \mathrm{~min}$ in a $0.75 \%$ (w:v) $\mathrm{M}$ glycine- $\mathrm{HCl}$ buffer $(0.045 \mathrm{M})$ at $\mathrm{pH} 3.0$ after the first staining sequence. In the alkaline phosphatase method, endogenous phosphatase activity was blocked with $0.025 \%$ (w:v) levamisol (Sigma) and $0.01 \%$ (w:v) $\mathrm{NaNO}_{2}$ (Merck).

Counterstaining of single and double immunolabeled sections was performed with Mayer's hematoxylin (Merck) for $15 \mathrm{~s}$, followed by rinsing in $10 \%$ ammonia and tap water.

\section{Cryo-immunohistochemistry}

A detailed list of the mAb used for cryo-immunohistochemistry of human AP is given in Table 3. Moreover, rat $\mathrm{m} \theta$-specific mAbs (ED1, ED2, ED3, ED7, ED8, ED9) (34, 35) were kindly provided by Dr Christine D. Dijkstra (Free University Amsterdam). Specific antisera used for identification of rat dendritic cells and FS cells were the monoclonals OX6 and OX62 (Sera-Lab, Sussex, UK) and polyclonal anti-S100 (Dakopatts), respectively. Cryo-sections were dried for $2-3 \mathrm{~h}$ at room temperature and then fixed with either acetone (Merck) for $5 \mathrm{~min}, 0.012 \%$ hexazotized pararosaniline (Sigma) for $2 \mathrm{~min}$ (66), or with Zambonifixative (67) prepared as described previously (68) for $2-4 \mathrm{~h}$. The latter fixation method was preferred for immuno-labeling of the diffusible cytoplasmic S100 protein $(29,32)$, whereas the former two fixatives were preferable for immunolabeling of membrane-bound lymphoid cell markers. In some additional experiments ( 4 independent preparations of 3 or 4 adult female rats) double immunolabeling was performed after fixation with freshly prepared PLP-solution (58), similar to the fixation procedure used for immuno-electron microscopy (see section below). In these experiments, the latter fixation procedure is a compromise choice for double immunolabeling of the $\$ 100$ protein together with the OX6 or OX62 markers.

Single immunostaining procedures were performed according to the PAP method (cfr. above) with DAB or AEC as staining reagent. Following incubation with the primary antibodies diluted in PBS with $1 \%$ bovine serum albumin (BSA; Sigma), the cryo-sections were incubated with normal rabbit or swine sera (Dakopatts) (4\% [v:v] in PBS + BSA) corresponding to the animal species in which the secondary antisera were raised, in order to prevent non-specific staining. For comparison of background staining in the different procedures, incubations with normal sera were performed preceding and subsequent to the incubation with the primary antibodies. Moreover, incubation of peroxidase(HRP)-labeled rabbit anti-mouse Ig (Dakopatts) or swine anti-rabbit Ig (Dakopatt's) was performed in the presence or absence of $4 \%$ (v:v) normal human pool serum (Bloedbank, The Hague, the Netherlands) or 4\% heatinactivated normal Wistar rat serum, for immunostaining of human or rat tissue, respectively. Human tonsillar lymphoid tissue and rat spleen or lymph nodes were used as positive control tissues. Endogenous peroxidase activity was examined in control sections treated with all incubation steps except the primary antiserum. Counterstaining with Mayer's hematoxylin and mounting of the sections was as described for the paraffin sections.

Double immunostaining procedures consisted of a combination of 
TABLE 3. Immunologic Markers used for the Characterization of Cells of the Monocyte-Macrophage-Dendritic Cell Lineage Present in the Human Anterior Pituitary

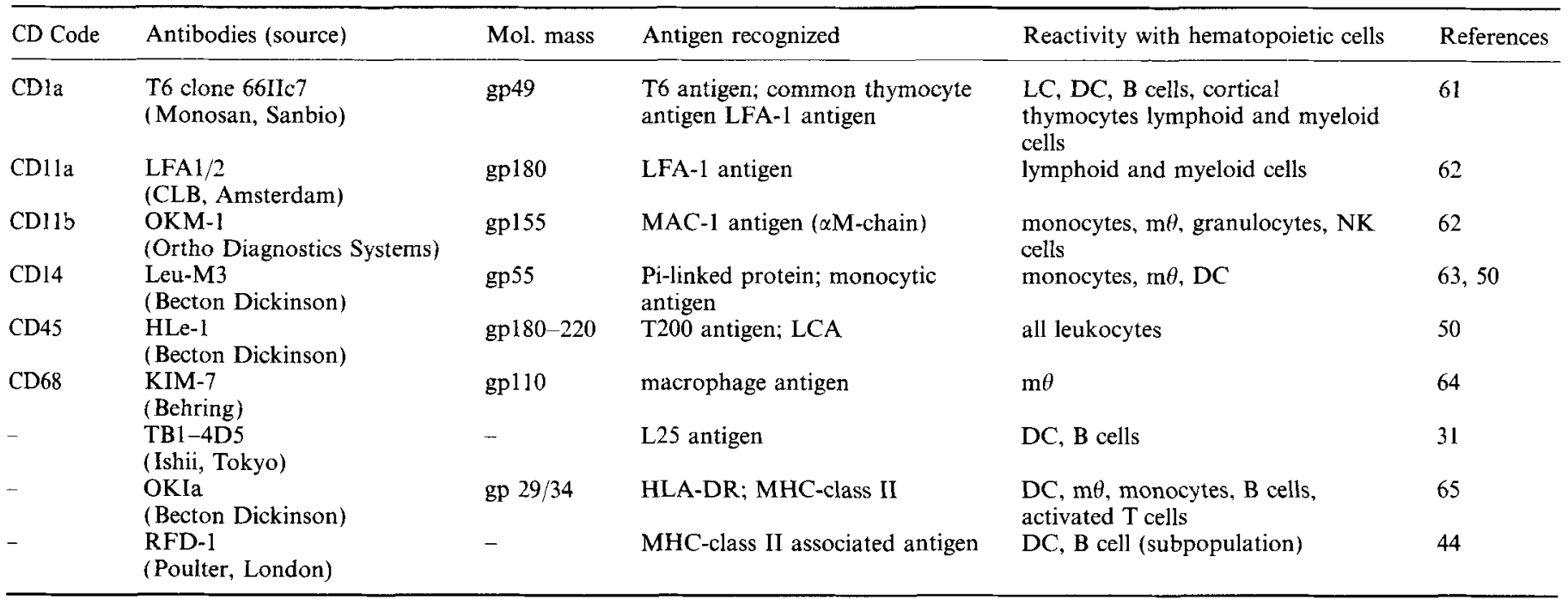

CD Cluster of differentiation as defined during the leukocyte typing conference. gp glycoprotein. LCA Leukocyte common antigen. LFA Leukocyte function antigen. PI Phosphatidyl-inositol glycan. MHC Major histocompatibility complex. NK Natural killer cell.

the indirect HRP-labeled antibody method (cfr. above) and the alkaline phosphatase-anti-alkaline phosphatase (APAAP)-method. Staining reagents of both methods were AEC and fast blue, respectively. The cryosections were incubated with a mixture of two primary antibodies (listed in Table 3 ) and subsequently incubated with $4 \%$ normal rabbit serum (Dakopatts). Thereafter, the sections were developed in a first staining sequence by incubation with either HRP-labeled rabbit anti-mouse Ig or unlabeled rabbit anti-mouse followed by mouse APAAP (all secondary antisera from Dakopatts). Secondary antibodies were diluted in PBS with BSA and 4\% (v:v) normal human pool serum (cfr. above). In a second staining sequence, the sections that had been developed according to the HRP-labeled method were further developed according to the APAAP method, and vice versa. Method specificity was tested by successively omitting the primary antiserum, the first and second staining sequence conjugates and the staining substrate.

\section{Immuno-electron microscopy}

Halved pituitaries from Wistar rats were fixed in PLP-solution (58) containing $2 \%$ ( $w: v)$ paraformaldehyde (UCB, Brussels, Belgium), $0.01 \mathrm{M}$ $\mathrm{NaIO}_{4}$ (Merck) and $0.075 \mathrm{M}$ L-lysine (BDH Chemicals) in $0.0375 \mathrm{M}$ sodium phosphate buffer. Tissue blocks were fixed for $1 \mathrm{~h}$ on ice, and pretreated with $2.3 \mathrm{M}$ sucrose in 0.I M PBS as a cryo-protectant (69). Cryoprotection was performed using increasing concentrations of glycerol $(10 \%-20 \%-30 \%)(70)$. The tissue blocks were sandwiched with a tweezer between a small piece of plastic (Thermonox) and two low-mass copper platelets and rapidly frozen into the KF80 apparatus (Reichert). Tissue blocks were freeze substituted and embedded in the low temperature resin HM20 (Lowicryl) (70), whereafter ultrathin sections were cut for immunolabeling. Cryo-substitution of the frozen aqueous constituents of the tissue blocks was done in the C.S-auto (Reichert) at $-90^{\circ} \mathrm{C}$ using a mixture of $0.5 \%$ uranyl acetate in methanol during $30 \mathrm{~h}$. Then the temperature was raised with $4{ }^{\circ} \mathrm{C}$ per $\mathrm{h}$ to $-45^{\circ} \mathrm{C}$ and the samples were slowly impregnated in increasing concentrations of Lowicryl HM20. Polymerization took place at $-45^{\circ} \mathrm{C}$ using an UV light source attached to the CS-auto apparatus. After 1 to 3 days post-polymerization at room temperature, ultrathin sections were cut with the OMU III (Reichert) and transferred to copper grids for immunolabeling.

For comparing the effect of cryo-substitution and UV-polymerization upon the antigenicity of the tissue, in another series of pituitaries the Tokuyasu thawed cryo-section technique (post-sectioning immunolabeling) was used (71). Technical details of this procedure are published elsewhere (74). Not-embedded but cryo-protected tissue blocks were cut into ultrathin cryo-sections of $80-90 \mathrm{~nm}$ with the FC4 ultramicrotome with diamond knife at $-100^{\circ} \mathrm{C}$. Immunolabeling of ultrathin cryo- sections and ultrathin resin-sections was performed according to the immunogold staining method (72).

Dilutions of antisera and immunogold complexes were made in $0.1 \mathrm{M}$ PBS containing $0.05 \%$ (w:v) of the acetylated and (partly) linearized BSA combined with $0.05 \%$ (v:v) Tween-20 (Aurion BSA-C; Aurion, Wageningen, the Netherlands) in order to prevent background by hydrophobic interaction. Prior to labeling and between the incubations with primary $\mathrm{mAbs}$ and immunogold, the sections were rinsed 3 times in $0.2 \%$ glycine (Fluka) in $0.1 \mathrm{M}$ PBS. Primary antisera used were the anti-rat MHC-class II mAb (OX6; gift of dr. N. Barclay, Oxford, UK) in dilutions between $1: 2$ and $1: 10$ and the polyclonal anti-bovine-S100 (Dakopatts), diluted $1: 100$ to $1: 25$. Immunogold staining was performed using the goat anti-mouse IgG-25 nm gold complex (Aurion) diluted $1: 20$. Double immunostaining was performed by first incubating the grids with the OX6 mAb followed by a rabbit-anti-mouse IgG- $25 \mathrm{~nm}$ gold complex (Aurion) (diluted 1:20), whereafter the grids were rinsed in PBS-glycine $(0.2 \%)$. For the second sequence, grids were incubated with the anti-S100 serum followed by a protein A-15 nm gold complex (Aurion) (diluted $1: 20)$.

Contrasting and air-drying of the sections was performed according to Tokuyasu's method (73). After three rinses in distilled water the grids were placed on a drop of filtered 4\% (w:v) uranyl acetate $(\mathrm{pH} 8.0)$ in $0.3 \mathrm{M}$ oxalic acid for $3 \mathrm{~min}$, and subsequently placed on a drop of $1.2 \%$ (w:v) low viscosity methyl cellulose $(0.25$ poise; Sigma) and filtered $1 \%$ uranyl acetate ( $\mathrm{pH} 4.0$ ) in distilled water for 3 min. Grids were examined in a Philips EM 301 electron microscope.

\section{Acknowledgements}

We thank Dr N. Barclay (Oxford University) and Dr Christine D. Dijkstra (Free University of Amsterdam) for their generous gifts of mAbs. Mrs Inge L. Schadee-Eestermans (Free University of Amsterdam) is acknowledged for introducing and assisting with the cryo-immuno EM and Ms Frieda van der Ham (Erasmus University of Rotterdam) is acknowledged for the assistance with the paraffin immunohistochemistry and human pituitary. We also thank Mrs Martha O. Canning for correcting English style, $\mathrm{Mr}$ Shimon Paniry and $\mathrm{Mr}$ Tar van Os for assisting with the EM and LM photography, respectively, and Ms Annelies C. de Vries and Petra Assems for the typographical work. This work was supported by NWO-MEDIGON grant number 900-543-089.

\section{Accepted 26 September 1995}




\section{References}

1. Tew J, Kosco MH, Burton GF, Szakal AK. (1990). Follicular dendritic cells as accessory cells. Immunological Rev. 117: 185-211.

2. Tew JG. (1993). Follicular dendritic cells and dendritic cell nomenclature. In: Kamperdijk EWA, Nieuwenhuis P, Hoefsmit ECM eds. Dendritic cells in fundamental and clinical immunology. Adv Exp Med Biol. 329: 467-468. Plenum Publishing Co, New York.

3. Steinman RM, Lustig DS, Cohn ZA. (1974). Identification of a novel cell type in peripheral lymphoid organs of mice. III. Functional properties in vivo. J Exp Med. 139: 1431-1445.

4. Drexhage HA, Mullink H, de Groot J, Clarke J, Balfour BM. (1979). A study of cells present in peripheral lymph of pigs with special reference to a type of cell resembling the Langerhans cell. Cell Tissue Res. 202: 407-430.

5. Hoefsmit ECM, Duijvestijn AM, Kamperdijk EWA. (1982). Relation between Langerhans cells, veiled cells, and interdigitating cells. Immunobiology. 161: 255-265.

6. Knight SC. (1984). Veiled cells-'dendritic cells' of the peripheral lymph. Immunobiology. 168: 349-361.

7. Steinman RM, Cohn ZA. (1973). Identification of a novel cell type in peripheral lymphoid organs of mice. I. Morphology, quantitation, tissue distribution. J Exp Med. 137: 1142-1162.

8. Klinkert WEF, Labadie JH, Bowers WE. (1982). Accessory and stimulating properties of dendritic cells and macrophages isolated from various rat tissues. J Exp Med. 156: 1-19.

9. Steinman RM, Cohn ZA. (1974). Identification of a novel cell type in peripheral lymphoid organs of mice. II. Functional properties in vitro. J Exp Med. 139: 380-397.

10. Inaba K, Steinman RM. (1987). Monoclonal antibodies to LFA-I and to CD4 inhibit the mixed leukocyte reaction after the antigen independent clustering of dendritic cells and lymphocytes. J Exp Med. 165: 1403-1417

11. Stingl G, Tamaki K, Katz SI. (1980). Origin and function of epidermal Langerhans cells. Immunological Rev. 53: 149-174.

13. Wilders MM, Sminia T, Janse EM. (1983). Ontogeny of nonlymphoid and lymphoid cells in the rat gut with special reference to large mononuclear Ia-positive dendritic cells. Immunology. 50: 303-314.

14. Nelson DJ, McMenamin Ch, McWilliams AS, Brenan M, Holt PG. (1994). Development of the airway intraepithelial dendritic cell network in the rat from class II major histocompatibility (Ia)-negative precursors: differential regulation of Ia expression at different levels of the respiratory tract. J Exp Med. 179: 203-212.

15. Kabel PJ, Voorbij HAM, de Haan M, van der Gaag RD, Drexhage HA. (1988). Intrathȳroidal dendritic cells. J Clin Endocrinol Metab. 65: 199-207

16. Voorbij HAM, Jeucken PHM, Kabel PJ, de Haan M, Drexhage HA. (1989). Dendritic cells and scavenger macrophages in pancreatic islets of prediabetic BB rats. Diabetes. 38: 1623-1629.

17. Nussenzweig MC, Steinman RM, Unkeless JC, Witmer MD, Gutchinov B, Cohn ZA. (1981). Studies of the cell surface of mouse dendritic cells and other leukocytes. J Exp Medicine. 154: 168-187.

18. Steinman RM, Nussenzweig MC. (1980). Dendritic cells: features and functions. Immunological Rev. 53: 127-147.

19. Rinehart JF, Farquhar MG. (1953). Electron microscopic studies of the anterior pituitary gland. J Histochem Cytochem. 1: 93-113.

20. Vila-Porcile E. (1972). Le réseau des cellules folliculo-stellaires et les follicules de l'adénohypophyse du rat (pars distalis). Z Zellforsch. 129: $328-369$

21. Cocchia D, Miani N. (1980). Immunocytochemical localization of the brain-specific $\$ 100$ protein in the pituitary gland of adult rat. J Neurocytol. 9: 771-782.

22. Nakajima T, Yamaguchi H, Takahashi K. (1980). S100 protein in folliculo-stellate cells of the rat pituitary anterior lobe. Brain Res. 191: 523-531.

23. Baes M, Allaerts W, Denef C. (1987). Evidence for functional communication between folliculo-stellate cells and hormone-secreting cells in perifused anterior pituitary cell aggregates. Endocrinology. 120: 685-691.

24. Allaerts W, Denef C. (1989). Regulatory activity and topological distribution of folliculo-stellate celis in rat anterior pituitary cell aggregates. Neuroendocrinology. 49: 409-418.

25. Allaerts W, Jeucken PHM, Hofland LJ, Drexhage HA. (1991).
Morphological, immunohistochemical and functional homologies between pituitary folliculo-stellate cells and lymphoid dendritic cells. Acta Endocrinol (Copenh). 125: 92-97.

26. Girod C, Trouillas J, Dubois MP. (1985). Immunocytochemical localization of S100 protein in stellate cells (folliculo-stellate cells) of the anterior lobe of the normal human pituitary. Cell Tissue Res. 241: $505-511$.

27. Vila-Porcile E. (1973). La pars distalis de l'hypophyse chez le rat. Contribution à son étude histologique et cytologique en microscopie électronique. Annals Sci Nat Zool. Paris, Serie 12, 15: 61-138.

28. Kligman D, Hilt DC. (1988). The S100 protein family. TIBS. 13: $437-443$.

29. Allaerts W, Carmeliet P, Denef C. (1990). New perspectives in the function of pituitary folliculo-stellate cells. Mol Cell Endocrinol. 71: 73-81

30. Coates PJ, Doniach I. (1988). Development of folliculo-stellate cells in the human pituitary. Acta Endocrinol (Copenh). 119: 16-20.

31. Ishii Y, Takami T, Kokai Y, Yuasa H, Fujimoto J, Takei T, Kikuchi K. (1985). A novel human B-lymphocyte antigen shared with lymphoid dendritic cells: characterization by monoclonal antibody. Clin Exp Immunol. 61: 624-632.

32. Allaerts W, Mignon A, Denef C. (1991). Selectivity of juxtaposition between cup-shaped lactotrophs and gonadotrophs from rat anterior pituitary in culture. Cell Tissue Res. 263: 217-225.

33. Brenan M. Puklavec M. (1992). The MRC OX-62 antigen: a useful marker in the purification of rat veiled cells with the biochemical properties of an integrin. J Exp Med. 175: 1457-1465.

34. Dijkstra CD, Döpp EA, Joling P, Kraal G. (1985). The heterogeneity of mononuclear phagocytes in lymphoid organs: distinct macrophage subpopulations in the rat recognized by monoclonal antibodies ED1, ED2 and ED3. Immunology, 54: 589-599.

35. Damoiseaux JGMC, Döpp EA, Neefjes JJ, Beelen RHJ, Dijkstra CD. (1989). Heterogeneity of macrophages in the rat evidenced by variability in determinants: two new anti-rat macrophage antibodies against a heterodimer of 160 and $95 \mathrm{kD}$ (CD11/CD18). J Leukocyte Biol. 46: 556-564.

36. Arkema JMS, Schadee-Eestermans IL, Broekhuis-Fluitsma DM, Hoefsmit ECM. (1991). Localization of class II molecules in storage vesicles, endosomes and lysosomes in human dendritic cells. Immunobiology. 183: 396-407.

37. Salazar H. (1963). The pars distalis of the female rabbit hypophysis: an electron microscopic study. Anat Rec. 147: 469-497.

38. Kagayama M. (1965). The follicular cell in the pars distalis of the dog pituitary gland: an electron microscopic study. Endocrinology. 77: $1053-1060$

39. Cocchia D, Michetti F, Donato R. (1981). Immunochemical and immunocytochemical localization of $\mathrm{S} 100$ antigen in normal human skin. Nature. 294: 85-87.

40. Takahashi K, Yamaguchi H, Ishizeki J, Nakajima T, Nakazato Y. (1981). Immunohistochemical and immunoelectronmicroscopic localization of S100 protein in the interdigitating reticulum cells of the human lymph node. Virchows Arch Abt B Cell Pathol. 37: 125-135.

41. Uccini S, Vitolo D, Stoppacciaro A, Paliotta D, Cassano AM, Barsotti P, Ruco LP, Baroni CD. (1986). Immunoreactivity for S100 protein in dendritic and in lymphocyte-like cells in human lymphoid tissues. Virchows Arch Abt B Cell Pathol. 52: 129-141.

42. Kamperdijk EWA, Kapsenberg ML, van den Berg M, Hoefsmit ECM. (1985). Characterization of dendritic cells, isolated from normal and stimulated lymph nodes of the rat. Cell Tissue Res. 242: 469-474.

43. Arkema JMS, Schadee-Eestermans IL, Beelen RHJ, Hoefsmit ECM. (1991). A combined method for both endogenous myeloperoxidase and acid phosphatase cytochemistry as well as immunoperoxidase surface labelling discriminating human peripheral blood derived dendritic cells and monocytes. Histochemistry. 95: 573-578.

44. Poulter LW, Campbell DA, Munro C, Janossy G. (1986). Discrimination of human macrophages and dendritic cells by means of monoclonal antibodies. Scand J Immunol. 24: 351-357.

45. Birbeck MS, Breathnach AS, Everall JD. (1961). An electron microscope study of basal melanocytes and high-level clear cells (Langerhans cells) in vitiligo. J Invest Dermatol. 37: 51-64.

46. Nakagawa F, Schulte BA, Spicer SA. (1985). Glucoconjugate localization with lectin and PA-TCH-SP cytochemistry in rat hypophysis. Am J Anat. 174: 61-81. 
47. Sbarbati A, Zancanaro C, Cinti S, Osculati F. (1988). Marginal and folliculo-stellate cells of the pituitary gland of the rat. A comparative morphometric study in lactating animals. Acta Anat. 131: 47-51.

48. Allaerts W, Jeucken PHM, Bosman FT, Drexhage HA. (1993). Relationsinip between dendritic cells and folliculo-stellate cells in the pituitary: immunohistochemical comparison between mouse, rat and human pituitaries. In: Kamperdijk EWA, Nieuwenhuis P, Hoefsmit ECM eds. Dendritic cells in fundamental and clinical immunology. Adv Exp Med Biol. 329: 637-642. Plenum Publishing Co, New York.

49. Sasaki A, Ogawa A, Hirato J, Nakazato Y. (1993). An immunohistochemical study of human pituicytes demonstrating frequent expression of MHC class II antigens and macrophage markers. Virchows Arch B Cell Pathol. 64: 379-386.

50. Freudenthal PS, Steinman RM. (1990). The distinct surface of human blood dendritic cells, as observed after an improved isolation method. Proc Natl Acad Sci USA. 87: 7698-7702.

51. Tachibana O, Yamashima T. (1988). Immunohistochemical study of folliculo-stellate cells in human pituitary adenomas. Acta Neuropathol. 76: $458-464$.

52. Gon G. (1987). The origin of ciliated cell cysts of the anterior pituitary. An experimental study in the rat. Virchows Arch Abt A Pathol Anat Histopathol. 412: 1-9.

53. Hume DA, Halpin D, Charlton H, Gordon S. (1984). The mononuclear phagocyte system of the mouse defined by immunohistochemical localization of antigen F4/80: macrophages of endocrine organs. Proc Natl Acad Sci USA. 81: 4174-4177.

54. Austyn JM, Gordon S. (1981). F4/80: a monoclonal antibody directed specifically against the mouse macrophage. Eur J Immunol 11: 805-815.

55. Gordon S, Fraser I, Nath D, Hughes D, Clarke S. (1992). Macrophages in tissues and in vitro. Curr Op Immunol. 4: 25-32.

56. Vankelecom $\mathbf{H}$, Matthys $\mathrm{P}$, Van Damme J, Heremans H, Billiau A, Denef C. (1993). Immunocytochemical evidence that S-100-positive cells of the mouse anterior pituitary contain interleukin-6 immunoreactivity. J Histochem Cytochem. 41: 151-156.

57. Allaerts W, Drexhage HA. (1994). Dendritic cells in autoimmune disease. In: Bruijnzeel-Koomen C, Hoefsmit ECM, eds Immunopharmacology of macrophages and other antigen presenting cells. 117-134. Academic Press Ltd, New York.

58. McLean JW, Nakane PK. (1974). Periodate-lysine-paraformaldehyde fixative: a new fixative for immunoelectron microscopy. J Histochem Cytochem. 22: 1077-1083

59. Hsu S-M, Raine L, Fanger H. (1981). Use of avidin-biotin-peroxidase complex $(\mathrm{ABC})$ in immunoperoxidase techniques: a comparison between $\mathrm{ABC}$ and unlabeled antibody (PAP) procedures. J Histochem Cytochem. 29: 577-580.

60. Sternberger LA. (1974). The unlabeled antibody enzyme method. In: Sternberger LA. Immunocytochemistry. (monograph): 129-171. Prentice Hail Inc., Englewood Cliffs, New Jersey.
61. Fithian E, Kung $P$, Goldstein G, Rubenfeld M. Fenoglio C, Edelson R. (1981). Reactivity of Langerhans cells with hybridoma antibody. Proc Natl Acad Sci USA. 78: 2541-2544.

62. Sanchez-Madrid F, Nagy JA, Robbins E, Simon P, Springer TA. (1983). A human leukocyte differentiation antigen family with distinct $\alpha$-subunits and a common $\beta$-subunit: the lymphocyte functionassociated antigen (LFA-1), the C3bi complement receptor (OKM1/Mac-1) and the p150,95 molecule. J Exp Med. 158: 1783-1785.

63. Thomas R, Davis LS, Lipsky PE. (1993). Isolation and characterization of human peripheral blood dendritic cells. J Immunol. 150: 821-843.

64. Radzun HJ, Kreipe H, Zavazava N, Hansmann HL, Parwaresch MR. (1988). Diversity of the human monocyte/macrophage system as detected by monoclonal antibodies. J Leukocyte Biol. 43: 41-50.

65. Reinherz EL, Kung PC, Pesando JM, Ritz J, Goldstein G, Schlossmann SF. (1979). Ia determinants on human T-cell subsets defined by monoclonal antibody. Activation stimuli required for expression. J Exp Med. 150: 1472-1482

66. de Jong JP, Voerman JSA, Leenen PJM, van der Sluijs-Gelling AJ, Ploemacher RE. (1991). Improved fixation of frozen lymphohaemopoietic tissue sections with hexazotised pararosaniline. Histochem J. 23: 392-401.

67. Zamboni L, De Martino C. (1967). Buffered picric acid-formaldehyde: a new, rapid fixative for electron microscopy. J Cell Biol. 35: 148A.

68. Denef C, Hautekeete E, De Wolf A. Van der Schueren B. (1978). Pituitary basophils from immature male and female rats: distribution of gonadotrophs and thyrotrophs as studied by unit gravity sedimentation. Endocrinology. 103: 724-735.

69. Griffiths G. (1993). Fine structure immunocytochemistry. Springer Verlag, Heidelberg.

70. Schadee-Eestermans IL, Hoefsmit ECM, Crocker P, Verkleij A. (1990). Post embedding immunocytochemistry of subsinusoidal lymph node compared to ultrathin cryosections. Micron and Microscopica Acta. 21: 269-270.

71. Tokuyasu KT. (1973). A technique for ultracryotomy of cell suspensions and tissues. J Cell Biol. 57: 551-565.

72. De Mey J, Moeremans M, Geuens G, Nuydens R, De Brabander M. (1981). High resolution light and electron microscopic localization of tubulin with the IGS (Immunogold staining) method. Cell Biol Int Rep. 3: 889 .

73. Tokuyasu KT. (1978). A study of positive staining of ultrathin frozen sections. J Ultrastruct Res. 63: 287-307.

74. Allaerts W. ( 1995). Functional communication between the endocrine and immune system at the pituitary: pleiotropism or transient differentiation stages within the folliculo-stellate and dendritic cell group? Belg J Zool. 125: 29-51. 